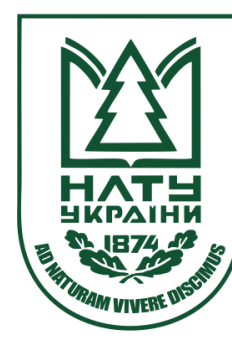

Науковий вісник НЛТУ України Scientific Bulletin of UNFU

http://nv.nltu.edu.ua

https://doi.org/10.15421/40290414

$@ \bowtie$ Correspondence author

Article received 13.03.2019 p.

Article accepted 25.04.2019 p.

V. O. Mandryk

УдК 336.71

\title{
ЗАКОНОДАВЧЕ РЕГУЛЮВАННЯ ОБІГУ КРИПТОВАЛЮТ В УКРАЇНІ, ПРОБЛЕМИ ТА ПЕРСПЕКТИВИ ЇХ РОЗВИТКУ
}

\begin{abstract}
Швидкий розвиток технологічних інновацій супроводжується змінами в перенесенні розрахунків у електронний формат, що зумовлює появу нових платіжних інструментів. Із розвитком інформаційних технологій виникає багато нових і різноманітних форм грошей, зокрема електронні гроші та криптовалюти. Розглянуто зарубіжний досвід регулювання обігу криптовалют, зокрема окреслено основні позиції фінансових інституцій. Висвітлено позицію НБУ стосовно обігу криптовалют в Україні та запропоновано зміни законодавчо-нормативного регулювання обігу криптовалют, що передбачені у проектах законів. Проаналізовано проблеми оподаткування майнінгу, пов'язані з використанням віртуальних криптовалют для нелегальних трансакцій, торгівлі наркотиками, зброєю та іншими забороненими товарами, втрати державної монополії на емісію грошей, зниження сеньйоражу центральних банків, зменшення попиту на національну валюту, що зумовлює ії знецінення, зміну швидкості обігу, що ускладнює процес визначення швидкості грошей і проведення грошово-кредитного регулювання, неможливість проведення ефективної грошово-кредитної політики, зменшення рівня впливу та усунення фінансових посередників та ін. Окреслено основні напрями вдосконалення регулювання обігу криптовалют на основі порівняння чинного в Україні законодавства з економічно розвиненими країнами Європейського Союзу та світу.
\end{abstract}

Ключові слова: криптовалюта; майнінг; електронні гроші; віртуальна валюта біткоїн; фіатні гроші; криптовалютні біржі.

Вступ. За умов швидкого розвитку технологічних інновацій відбуваються істотні зміни в усіх сферах господарювання, зокрема і у фінансовому секторі. Виявляються ці зміни насамперед у перенесенні розрахунків у електронний формат, що зумовлює появу нових платіжних інструментів. Взагалі в розрахункових системах протягом останнього часу відбулися революційні зміни, що зумовлені появою нового програмного забезпечення.

XXI ст. ознаменувалося швидким розвитком мобільних технологій та Інтернету. 3 розвитком інформаційних технологій, ідеї людства поступово стають реальністю, виникає багато нових і різноманітних форм грошей, зокрема електронні гроші та криптовалюти (Agency, 2019).

Криптовалюта (англ. Cryptocurrency or Crypto Cur$r e n c y)$ - це цифровий актив, що є засобом обміну та використовує криптографію для безпеки своїх транзакцій, контролю створення додаткових одиниць та для перевірки передачі активів. Криптовалюта - це тип цифрових валют, альтернативних валют та віртуальних валют. Жодний центральний орган не видає криптовалюту, що робить іiі абсолютно захищеною до державного втручання або маніпулювання (Maininh, 2019).

3 огляд на швидке впровадження інновацій у сферу платіжних і розрахункових систем, зокрема обігу криптовалюти, виникають питання, що стосуються нормативного регулювання та їх практичного використання у
Національній платіжній системі України (Bitcoin, 2019).

Розглянувши міжнародний досвід законодавчого регулювання щодо питання функціонування криптовалют, зможемо з'ясувати: чи існує сьогодні єдине бачення регулювання криптовалютної діяльності. Проаналізуємо нормативно-законодавчу базу діяльності криптовалютних бірж, майнінг (mining) та вивід у фіат.

Аналіз останніх досліджень і публікацій. Питань функціонування електронних грошей та безготівкових розрахунків стосуються праці таких вітчизняних та зарубіжних вчених, як: М. Савлук, М. Алексеєнко, Е. Горюков, М. Шевчук, В. Міщенко, О. Махаєва, О. Мельниченко, О. Гринишин, Н. Пантєлєєва, П. Сенищ, М. Фрідмен та інші науковці. Водночас у наукових працях не приділено достатньо уваги питанням емісії, використання та регулювання криптовалют для їх імплементації у функціонування Національної платіжної системи України.

Метою роботи є аналіз зарубіжного досвіду ідентифікації та сутності різновидів криптовалюти, аналіз іiі емісії, можливостей законодавчого регулювання іiї обігу і позиції НБУ та центральних банків зарубіжних країн до її визнання.

Викладення основного матеріалу дослідження. Криптографію для проведення конфіденційних платежів почали використовувати з 1990 р. в системі DigiCash Девіда Чома, компанія якого збанкрутувала в

\section{Інформація про авторів:}

Мандрик Василь Олегович, канд. екон. наук, доцент, кафедра обліку і аудиту. Email: mandryk@nltu.edu.ua

Мороз Володимир Павлович, канд. екон. наук, доцент, кафедри обліку і фінансів. Email: volodia-moroz@i.ua

Цитування за ДСтУ: Мандрик В. О., Мороз В. П. Законодавче регулювання обігу криптовалют в Україні, проблеми та перспективи їх розвитку. Науковий вісник НЛтУ України. 2019, т. 29, № 4. С. 67-71.

Citation APA: Mandryk, V. O., \& Moroz, V. P. (2019). The legislative regulation of the circulation of cryptocurrency in Ukraine and the prospects for development. Scientific Bulletin of UNFU, 29(4), 67-71. https://doi.org/10.15421/40290414 
1998 р. Однак його платіжна система була централізованою, а вперше термін "криптовалюта" почали вживати після появи платіжної системи Bitcoin, яку розробила в 2009 р. людина або група осіб під псевдонімом Сатосі Накамото, яка поступово набуває популярності серед населення планети (Kryptovaliuta, 2019; Valiuty, 2019).

Зазвичай, є верхня межа загального обсягу емісії для (BTC) Bitcoin - 21 млн монет, (LTC) Litecoin - 84 млн монет. Однак у деяких криптовалют, таких як: PPCoin, Novacoin, Sifcoin та ін., відсутня фіксована верхня межа загального обсягу емісії і можлива як емісія за рахунок наявних накопичень, так і демісія способом обов'язкового знищення невеликої фіксованої суми в кожній транзакції (Kryptovaliuta, 2019).

Майнінг (від англ. мining - видобуток корисних копалин) - це спосіб заробітку біткоіна чи іншої криптовалюти за допомогою обчислювальних потужностей комп'ютера, зміст якого полягає у підтримці розподіленої платформи і створення нових блоків із можливістю отримати винагороду в формі емітованої валюти і комісійних зборів у різних криптовалютах, зокрема в Bitcoin. Вироблені обчислення потрібні для забезпечення захисту від повторного використання одних і тих же одиниць валюти, а зв'язок майнінгу 3 емісією стимулює людей витрачати свої обчислювальні потужності та підтримувати роботу мереж (Proekt zakonu, 2017).

Однією 3 функцій Національного банку України є монопольне здійснення емісії Національної валюти України та організація готівкового грошового обігу (ст. 7 Закону України "Про Національний банк України").

Випуск та обіг на території України інших грошових одиниць і використання грошових сурогатів, як засобу платежу, заборонено (частина друга статті 32 Закону України "Про Національний банк України").

Отож, Національний банк України надав роз'яснення щодо правомірності використання в Україні "віртуальної валюти/криптовалюти" Bitcoin. Національний банк України розглядає "віртуальну валюту/криптовалюту" Bitcoin як грошовий сурогат, який не має забезпечення реальною вартістю і його не можуть використовувати фізичні та юридичні особи на території України як засіб платежу, оскільки це суперечить нормам українського законодавства.

Наголошено, що всі ризики за використання в розрахунках "віртуальної валюти/криптовалюти" Bitcoin несе учасник розрахунків за ними. Національний банк України, як регулятор, не відповідає за можливі ризики i втрати, пов'язані з використанням "віртуальної валюти/криптовалюти" Bitcoin (Bitcoin, 2019).

Крім цього, відповідаючи на звернення щодо віднесення операцій з "віртуальною валютою/криптовалютою "Bitcoin" до операцій з торгівлі іноземною валютою, а також наявності підстав для зарахування на поточний рахунок в іноземній валюті фізичної особи іноземної валюти, отриманої від продажу Bitcoin, звернув увагу на таке: випуск віртуальної валюти Bitcoin не має будь-якого забезпечення та юридично зобов'язаних за нею осіб, не контролюється державними органами влади жодної із країн. Отже, Bitcoin $\epsilon$ грошовим сурогатом, який не має забезпечення реальної вартості.

У НБУ вважають, що діяльність з купівлі-продажу Bitcoin за долари США або іншу іноземну валюту має ознаки функціонування так званих "фінансових піра- мід" та може свідчити про потенційну залученість у здійсненні сумнівних операцій відповідно до законодавства про протидію легалізації (відмиванню) доходів, одержаних злочинним способом, і фінансуванню тероризму (MAS, 2019).

Водночас у НБУ звертають увагу на таке:

1. Свропейське банківське управління (European Banking Authority, EBA) (далі СБА) закликало банки Європейського співтовариства (далі $\mathrm{CC}$ ) утриматися від операцій 3 криптовалютами, зокрема Bitcoin доти, поки не буде створено систему правил, яка зможе запобігти зловживанням.

2. СБА рекомендувало владі ЄС розробити систему правил і захисних заходів для торгових платформ і створити окремі комісії зі спостереження за кожною електронною системою. Поки ж банкам варто утриматися від операцій $з$ купівлі-продажу або навіть володінням криптовалютами.

3. Також у НБУ застерігають громадян та юридичних осіб щодо використання віртуальних валют для обміну на товари або грошові кошти, оскільки це пов'язано з ризиком повної втрати коштів, що задіяні в таких операціях, а також ризиком залучення таких осіб до діяльності, пов'язаної з легалізацією (відмиванням) доходів, одержаних злочинним способом, і фінансуванням тероризму.

Таким способом НБУ прагне мінімізувати негативні наслідки від використання криптовалют у межах своїх безпосередніх функцій.

Пантелєєва Н. (Pantielieieva, 2015) звертає увагу на такі факти:

- використання віртуальних криптовалют для нелегальних трансакцій, торгівлі наркотиками, зброєю та іншими забороненими товарами;

- втрата державної монополії на емісію грошей;

- зменшення сеньйоражу центральних банків;

- зменшення попиту на національну валюту, що зумовлює іiі знецінення (а може навіть відмову на користь іноземної) та зміну швидкості обігу, що ускладнює процес визначення швидкості обігу грошей і проведення грошово-кредитного регулювання;

- неможливість проведення ефективної грошово-кредитної політики, оскільки вагома частка грошової маси перебуватиме поза контролем монетарного регулятора;

- зменшення рівня впливу або усунення фінансових посередників тощо.

Підходи до визначення правового статусу криптовалют істотно різняться між різними країнами та юрисдикціями світу: від повної заборони до визнання їх платіжним засобом. У переважній більшості країн криптовалюти не мають статусу платіжного засобу. Низка країн із числа тих, що розвиваються, заборонила обіг криптовалют із метою запобігання ризикам відпливу капіталу та/чи фінансування незаконної діяльності, інші стали на шлях їх повної легалізації.

Міжнародний досвід державного регулювання криптовалют представлено у таблиці (Internal Revenue Service, 2019). На сучасному етапі розвитку світової економіки використання криптовалюти значно розширюється, про що свідчить досвід зарубіжних партнерів. Можна стверджувати, що Велика Британія є найбільш прогресивною країною відносно використання криптовалюти (тут нараховується більше, ніж 30 bitcoin-банкоматів). Данія відкрито заявила про бажання якнайшвидше ліквідувати паперові гроші, тому безготівкові розрахунки та цифрова валюта досить поширені. У березні 
2016 р. Данія стала першою скандинавською країною, де купівлю нерухомості було здійснено за допомогою Bitcoin. Найсміливіше ставлення до криптовалюти продемонстрували Нідерланди, де було створено "місто Bitcoin", де визначено найвищу концентрацію компа- ній, що надають товари та послуги за Bitcoin. Тут можна не тільки сплатити юридичні послуги, а й підстригтися, купити гамбургер або новий костюм, надіслати листа, полагодити побутову техніку або зняти номер у готелі (Bitcoin, 2019).

Таблиця. Міжнародний досвід законодавчого регулювання функціонування криптовалют, криптовалютних бірж та майнінгу

\begin{tabular}{|c|c|c|c|c|c|}
\hline Країна & $\begin{array}{c}\text { Особливості } \\
\text { регулювання } \\
\end{array}$ & Криптовалюта & Криптовалютні біржі & Майнінг & Примітки \\
\hline 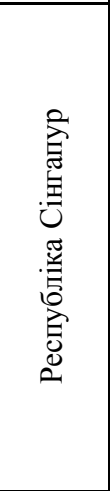 & $\begin{array}{l}\text { Грошово-кредит- } \\
\text { не управління } \\
\text { (MAS) та законо- } \\
\text { давство Сінгапу- } \\
\text { ру не регулюють } \\
\text { криптовалюту. }\end{array}$ & $\begin{array}{l}\text { Криптовалюта не } \\
\epsilon \text { законним пла- } \\
\text { тіжним засобом. } \\
\text { Вона не видається } \\
\text { урядом і не під- } \\
\text { кріплена активом } \\
\text { або їі емітентом. }\end{array}$ & $\begin{array}{l}\text { Криптовалютні біржі - це вірту- } \\
\text { альні валютні посередники, які } \\
\text { полегшують купівлю чи продаж } \\
\text { віртуальних валют, або створю- } \\
\text { ють платформу для того, щоб } \\
\text { дозволити особам обмінюватися } \\
\text { віртуальними валютами. Регу- } \\
\text { люються MAS для запобігання } \\
\text { відмиванню коштів та фінансу- } \\
\text { ванню тероризму. }\end{array}$ & \begin{tabular}{|l|} 
Діяльність \\
щодо майнін- \\
гу криптова- \\
люти не регу- \\
люється зако- \\
нодавством та \\
MAS.
\end{tabular} & $\begin{array}{l}21 \text { листопада } 2017 \text { р. MAS } \\
\text { опублікувало консультативний } \\
\text { документ щодо платіжних пос- } \\
\text { луг. Законопроект дасть змогу } \\
\text { розширити сферу регулювання } \\
\text { покупки та реалізації віртуаль- } \\
\text { ної валюти та інших інновацій, } \\
\text { що використовуються у внут- } \\
\text { рішніх грошових переказах та } \\
\text { торговельних операціях, за до- } \\
\text { помогою торгових точок або } \\
\text { он-лайн платежів. Платіжним } \\
\text { компаніям потрібно володіти } \\
\text { тільки однією ліцензією за єди- } \\
\text { ною регуляторною базою. }\end{array}$ \\
\hline . & $\begin{array}{l}\text { Закон Про валют- } \\
\text { не регулювання } \\
\text { регулює функці- } \\
\text { онування крипто- } \\
\text { валюти. Діяль- } \\
\text { ність криптова- } \\
\text { лютних бірж та } \\
\text { майнінгу регу- } \\
\text { люється Комі- } \\
\text { сією з цифрових } \\
\text { активів. }\end{array}$ & $\begin{array}{l}\text { Криптовалюта } \\
\text { визначається цін- } \\
\text { ністю подібною } \\
\text { активам. Біткоїн } \\
\text { класифікується як } \\
\text { свого роду перед- } \\
\text { плачений платіж- } \\
\text { ний інструмент. }\end{array}$ & $\begin{array}{l}\text { У разі відкриття криптовалютної } \\
\text { біржі, власники повинні: подава- } \\
\text { ти спеціальну заяву в Комісію } 3 \\
\text { цифрових активів; вживати від- } \\
\text { повідних заходів щодо протидії } \\
\text { легалізації (відмиванню) дохо- } \\
\text { дів, отриманих злочинним шля- } \\
\text { хом; вживати заходів щодо за- } \\
\text { безпечення безпеки; проводити } \\
\text { ідентифікацію клієнтів. Опера- } \\
\text { тори криптовалютних бірж під- } \\
\text { лягають реєстрації в Агентстві } \\
\text { фінансових послуг. }\end{array}$ & \multicolumn{2}{|c|}{$\begin{array}{l}1 \text { квітня } 2017 \text { р. парламентом Японії було ух- } \\
\text { валено Закон Про валютне регулювання, що } \\
\text { дає змогу використовувати цифрову валюту як } \\
\text { спосіб оплати та фактично надаючи їй такий } \\
\text { самий правовий статус, як і будь-якій валюті. }\end{array}$} \\
\hline 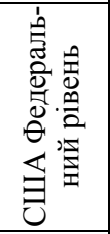 & $\begin{array}{l}\text { Функціонування } \\
\text { криптовалюти за- } \\
\text { конодавчо не ре- } \\
\text { гулюється. }\end{array}$ & $\begin{array}{l}\text { Не існує юридич- } \\
\text { ного єдиного по- } \\
\text { няття. }\end{array}$ & $\begin{array}{l}\text { Регулювання діяльності крипто- } \\
\text { валютних бірж здійснює Мережа } \\
3 \text { боротьби з фінансовими злочи- } \\
\text { нами (Financial Crimes Enforce- } \\
\text { ment Network). }\end{array}$ & \begin{tabular}{|l|} 
Діяльність \\
щодо майнін- \\
гу криптова- \\
люти не регу- \\
люється на \\
федеральному \\
рівні.
\end{tabular} & $\begin{array}{l}\text { У березні } 2014 \text { р. Служба внут- } \\
\text { рішніх доходів США опубліку- } \\
\text { вала посібник, в якому визначи- } \\
\text { ла криптовалюту як власність } \\
\text { (рroperty), операції з якою по- } \\
\text { винні обкладатися податками } \\
\text { (зокрема й майнінг). }\end{array}$ \\
\hline 管 & $\begin{array}{l}\text { Криптовалюта не } \\
\text { регулюється } \\
\text { Європейським } \\
\text { Центральним } \\
\text { банком (ЄЦБ) та } \\
\text { законодавством } \\
\text { ЄС. }\end{array}$ & $\begin{array}{l}\text { Криптовалюта } \\
\text { класифікується як } \\
\text { конвертована де- } \\
\text { централізована } \\
\text { віртуальна валю- } \\
\text { та. }\end{array}$ & $\begin{array}{l}\text { Криптовалютні біржі повинні } \\
\text { дотримуватися тих самих вимог, } \\
\text { що й банки та інші фінансові ус- } \\
\text { танови, проводити ідентифіка- } \\
\text { цію клієнтів та відстежувати пі- } \\
\text { дозрілу діяльність. Діяльність не } \\
\text { регулюється законодавством СС. }\end{array}$ & \begin{tabular}{|l|} 
Діяльність \\
щодо майнін- \\
гу криптова- \\
люти не регу- \\
люється зако- \\
нодавством \\
ЄС.
\end{tabular} & $\begin{array}{l}\text { У } 2015 \text { р. Свропейський суд } \\
\text { звільнив bitсоіп від оподатку- } \\
\text { вання, чим фактично визнав їі } \\
\text { повноцінною грошовою одини- } \\
\text { цею. Нею можна розраховува- } \\
\text { тись, і навіть зберігати як за- } \\
\text { ощадження. У } 2017 \text { р. внесено } \\
\text { зміни до Директиви ЄС щодо } \\
\text { боротьби з відмиванням гро- } \\
\text { шей, спрямовані на усунення } \\
\text { ризиків відмивання коштів та } \\
\text { фінансування тероризму за до- } \\
\text { помогою криптовалют. }\end{array}$ \\
\hline
\end{tabular}

Міністерство фінансів Німеччини офіційно визнало Bitcoin фінансовим інструментом та внесла відповідні зміни в Банківський кодекс. Франція так само, як і Україна, рекомендувала утриматися від використання Bitcoin. Фінляндія розглядає Bitcoin не як "валюту", а як "сировинний товар". Естонія відмовляється працювати 3 Bitcoin, як і найбільший скандинавський SEB Bank. У СШA Bitcoin розглядають як один із засобів платежів у електронній комерції. Так, наприклад, найбільший американський інтернет-магазин побутової техніки Overstock.com приймає для рахунку Bitcoin.

У столиці Австрії Відні відкрився перший у світі Bitcoin банк. Цей банк повинен зробити купівлю і продаж Bitcoin простішим та безпечнішим. У банку встановлено спеціальні банкомати, які допомагають обмі- нювати Bitcoin на євро і навпаки. Клієнти банку також можуть отримати цікаву для них інформацію про віртуальні валюти. Проект став досить успішним, і після нього Bitcoin банкомати почали з'являтися і в інших місцях.

Проте в таких країнах, як: Росія, Еквадор, Киргизія, використання Bitcoin було заборонено. У Китаї їх використання заборонено для фінансових інституцій. Тому виникає потребу нормативно-правового регулювання емісії криптовалют, їхнього обігу, моніторингу розвитку, побудови відповідних платіжних систем, відповідно до розвитку сучасних технологій в Україні. На сьогодні подано два законопроекти до Верховної Ради України № 7183 та 9083, які мають за мету законодавчо врегулювати обіг криптовалют в Україні. 
Проект закону № 7183 "Про обіг криптовалюти в Україні" вперше визначає поняття криптовалюти, визнає майнерів і наділяє НБУ статусом органу, який буде здійснювати управління у сфері обігу криптовалюти. Окрім цього, проект закону встановлює для майнерів вимогу платити податки і позбавляє криптовалюту ключової переваги для інвесторів - анонімності.

Автори проекту визначилися зі статусом криптовалюти. Так у ст. 1. п. 1. проекту Закону "Про обіг криптовалюти в Україні" за № 7183 визначено, що криптовалюта - це програмний код (набір символів, цифр та букв), що є об'єктом права власності, який може бути засобом міни, відомості про який вносяться та зберігаються у системі блокчейн як облікові одиниці поточної системи блокчейн у вигляді даних (програмного коду).

Відповідно до проекту закону, криптовалюта не зможе стати платіжним засобом, оскільки її суть суперечить всім чинним нормам українського законодавства. Сдиним законним платіжним засобом у нашій країні є гривня.

Визначення поняття електронних грошей також не можна використовувати до криптовалюти, оскільки в Україні їх емісією дозволено займатися тільки банкам. Причому тільки номінованим у гривні. Але навіть якщо перелік емітентів розширити, дозволивши випускати криптовалюту, то узгоджувати правила використання криптовалюти буде нікому. Оскільки за емісією віртуальних грошей не має конкретних організацій або фізичних осіб.

Проект закону також передбачає створення в Україні криптовалютних бірж, на яких українці зможуть легально обміняти свою криптовалюту на електронні гроші, цінні папери або валютні цінності. Тобто, фактично, вивести віртуальні кошти в реальний світ (варто звернути увагу, що така опція вже функціонує у Приватбанку).

Відповідно до проекту Закону, Національний банк України повинен розробити порядок створення та діяльності криптовалютних бірж, порядок моніторингу всіх транзакцій, ідентифікацію та персоніфікацію суб'єктів криптовалютних операцій як майнерів, так і власників криптовалютних рахунків. Це, фактично, позбавляе криптовалюту анонімного статусу, принаймні в частині операцій з виведення "програмного коду" в реальні гроші.

Проект закону також пропонує обкладати податком всі, без винятку, операції, пов'язані з криптовалютою. Отриману внаслідок майнінгу винагороду визнають об'єктом оподаткування. Тобто майнеру фізичній особі доведеться заплатити до державного бюджету 18 \% податку на доходи фізичних осіб і 1,5 \% військового збору.

Залишається невирішеним питання, від якої суми потрібно розраховувати податок і за яким курсом визначати базу оподаткування. Адже вартість криптовалюти змінюється щомиті, і загальносвітової ціни на неї не існує. Котирування на двох різних біржах можуть сильно відрізнятися.

Також, крім доходів майнерів, податками повинні обкладатися і всі операції з криптовалютою на українських біржах, а також доходи самих майданчиків. Правда, тут питань виникає ще більше. А за роз'ясненнями законопроект відсилає до "чинного" законодавства України.

Проект Закону № 9083 "Про внесення змін до Податкового кодексу України щодо оподаткування опера- цій з віртуальними активами в Україні" передбачає зміни, які інтегрують фактично існуючі в суспільстві правовідносини 3 обігу віртуальних активів до правовідносин суб'єктів, вже врегульованих податковим законодавством. Законопроектом вносяться точкові зміни до Розділу I. Загальні положення, Розділу III. Податок на прибуток підприємств, Розділу IV. Податок на доходи фізичних осіб, Розділу V. Податок на додану вартість, Розділу XX. Перехідні положення. Проект закону вводить в обіг з метою оподаткування такі поняття, як: віртуальні активи, токен, токен-актив, криптовалюта, емітент віртуального активу, майнінг, операції з віртуальними активами, прибуток від операцій з віртуальними активами тощо.

Віртуальним активом $є$ будь-яка форма запису в рамках розподіленого реєстру записів у цифровій формі, що можна використовувати як засіб обміну, одиницю обліку чи як засіб збереження вартості. При цьому токеном вважають цифрову одиницю обліку в рамках розподіленого реєстру записів у цифровій формі, який має криптографічний захист. У формі токенів функціонують такі віртуальні активи, як: криптовалюта - як засіб обміну та збереження вартості, та токен-актив, який посвідчує майнові права його власника, що відповідають зобов'язанням емітента. У сфері оподаткування прибутку підприємств законопроектом передбачено новий вид оподатковуваного прибутку - прибуток від операцій з віртуальними активами, якого традиційно визначено як позитивну різницю між доходом від продажу віртуальних активів (обміну їх на валютні цінності) та витратами на їх придбання та/або майнінг, під яким законопроект розуміє діяльність платника податків зі здійснення обчислень, спрямованих на підтримання роботи розподіленого реєстру записів у цифровій формі, зокрема з метою отримання віртуальних активів.

Проектом передбачено, що прибуток підприємств від операцій з віртуальними активами 31 січня 2024 р. оподатковуватиметься за базовою ставкою - 18 \%. Проте протягом періоду становлення правового регулювання ринку віртуальних активів, автори законопроекту вважають за необхідне тимчасово, до 31 грудня 2024 р., встановити ставку податку на прибуток підприємств для такого виду прибутку на рівні 5 \%. Виняток становить прибуток від операцій $з$ токенами-активами, які посвідчують права на товари, до прибутку від операцій, 3 якими застосовується ставка податку інша, ніж до прибутку від операцій з віртуальними активами. Особливостями цих правовідносин є те, що облік доходів та витрат, пов'язаних із операціями з віртуальними активами, платники мають вести окремо від доходів та витрат від іншої діяльності так само, як і визначати фінансовий результат і обчислювати суму податку.

Законопроектом передбачено, що податком на доходи фізичних осіб оподатковується:

- прибуток від операцій з віртуальними активами як позитивна різниця між доходом, отриманим від продажу віртуальних активів (обміну їх на валютні цінності), та витратами на їх придбання за умови їх документарного підтвердження або витратами на майнінг таких віртуальних активів;

- доходи від операцій з продажу віртуального активу в повному обсязі - у разі відсутності документарного підтвердження витрат на їх придбання. При цьому операції з обміну віртуального активу одного виду на інший не вважають операціями з продажу віртуальних активів, а операції з обміну віртуальних активів на інші об'єкти цивільних право- 
відносин, відмінні від віртуальних активів, вважають операціями $з$ продажу віртуальних активів за вартістю, що дорівнює договірній вартості об'єкту (об'єктів) цивільних правовідносин, які підлягають обміну на віртуальні активи.

До операцій, що не є об'єктом оподаткування ПДВ, законопроект відносить операції:

- $з$ емісії токенів-активів;

- $з$ обміну віртуальних активів одного виду на інший, за винятком постачання, продажу тих токен-активів, що посвідчують права на товари, постачання яких є об'єктом оподаткування;

- 3 постачання, продажу віртуальних активів, за винятком постачання, продажу тих токен-активів, що посвідчують права на товари, постачання яких є об'єктом оподаткування.

Прибуток (доходи) фізичних осіб від операцій з віртуальними активами оподатковується за ставкою 5 \%. Платник податку - фізична особа, яка самостійно відповідає за розрахунок прибутку від операцій з віртуальними активами і сплату податку на доходи фізичних осіб.

Таким чином, легалізація криптовалюти сприятиме наповненню дохідної частини державного бюджету. А питання нормативно-правового регулювання криптовалюти на території України є актуальним та необхідним, про що свідчить міжнародний досвід, криптовалюта стає щоразу популярнішою в міжнародній практиці, і їі розвиток зупинити практично неможливо й економічно недоцільно.

Поява криптовалюти з високим ступенем фінансової новизни призводить до революційних змін грошових відносин, та ставить нас на новий етап еволюції грошей. Це ставить нові виклики грошовій та платіжній системах та спонукає уряди держав до відповідної адаптації своїх фінансових інститутів. Проте залишається нез'ясованим питання щодо майбутнього глобальних фінансово-кредитних установ (МВФ, Світовиго банку та ін.).
Якщо зміни відбуваються, то це потрібно сприймати як належне відповідно до викликів та потреб III Тисячоліття, у час інформаційних технологій і технологічних інновацій, які мають бути забезпечені цифровими активами.

\section{Перелік використаної літератури}

Agency. (2019). Financial Services Agency. Retrieved from: http://www.fsa.go.jp/news/28/ginkou/20170324-1.html

Bitcoin. (2019). Uvedomlenie Narodnogo banka Kitaia o predotvrashhenii riskov Bitcoin. Retrieved from: http://smartlab.ru/blog/ news/154499.php. [In Russian].

Internal Revenue Service. (2019). Derzhavnyi orhan Federalnoho uriadu Spoluchenykh Shtativ Ameryky, yakyi zaimaietsia zborom podatkiv, kontroliuie vykonannia zakonodavstva pro opodatkuvannia ta tlumachyt podatkovyi kodeks. Retrieved from: https://www.irs.gov/. [In Ukrainian].

Kryptovaliuta. (2019). Retrieved from: https://uk.wikipedia.org/wiki. [In Ukrainian].

Maininh. (2019). Mizhnarodnyi dosvid zakonodavchoho rehuliuvannia pytannia funktsionuvannia kryptovaliut, kryptovaliutnykh birzh, maininhu ta vyvodu $\mathrm{v}$ fiat. Informatsiina dovidka, pidhotovlena Yevropeiskym informatsiino-doslidnytskym tsentrom. Retrieved from: http://radaprogram.org/sites/default/files/infocenter/piblicati ons/65.pdf. [In Ukrainian].

MAS. (2019). Monetary Authority of Singapore (MAS) - tse tsentralnyi bank Sinhapuru. Retrieved from: http://www.mas.gov.sg/. [In Ukrainian].

Pantielieieva, N. (2015). Novi formy hroshei v umovakh formuvannia informatsiinoho suspilstva. Visnyk Natsionalnoho banku Ukrainy, 5, 25-31. [In Ukrainian].

Proekt zakonu. (2017). "Pro obih kryptovaliuty v Ukraini" za №7183 vid 06.10.2017 r. Retrieved from: http://w1.c1.rada.gov.ua/pls/ zweb2/webproc41?pf3511=62684. [In Ukrainian].

Valiuty. (2019). Roziasnennia Natsionalnoho banku Ukrainy shchodo pravomirnosti vykorystannia v Ukraini "virtualnoi valiuty/kryptovaliuty" Bitcoin. Retrieved from: http://zakon2.rada.gov.ua/laws/ show/n0435500-14. [In Ukrainian].

V. O. Mandryk', V. P. Moroz ${ }^{2}$

${ }^{I}$ Ukrainian National Forestry University, Lviv, Ukraine

${ }^{2}$ Lviv Institute of Economy and Tourism, Lviv, Ukraine

\section{THE LEGISLATIVE REGULATION OF THE CIRCULATION OF CRYPTOCURRENCY IN UKRAINE AND THE PROSPECTS FOR DEVELOPMENT}

The rapid development of technological innovation is accompanied by changes in the transfer of settlements in electronic format, which leads to the emergence of new payment instruments. With the development of information technology there are many new and diverse forms of money, including electronic money and cryptocurrency. In connection with the rapid introduction of innovations in the sphere of payment and settlement systems, in particular, the circulation of cryptocurrency, a number of issues arise concerning regulatory regulation and it practical using in the national payment system of Ukraine. In the course of the study the foreign experience of regulating the circulation of cryptocurrency is considered, in particular, the main positions of financial institutions are outlined. The position of the National Bank of Ukraine regarding the circulation of cryptocurrency in Ukraine and the main proposed changes in the legislative and normative regulation of the cryptocurrency treatment provided for the draft laws are highlighted. The problems of taxation of mining related to the using of virtual cryptocurrency for illegal transactions, drug trafficking in arms and other prohibited goods, the loss of state monopoly on the issue of money, the reduction of the benchmark of central banks, the decrease in demand for national currency, which leads to its depreciation of the rate of turnover, which in turn complicates the process of determining the speed of money and the conduct of monetary regulation, the impossibility of an effective monetary policy, reducing the level of influence and elimination of financial intermediaries, etc.Legalization of cryptocurrency will help fill the revenue side of the state budget. And the issue of legal regu lation of cryptocurrency on the territory of Ukraine is relevant and necessary, as international experience shows, cryptocurrency is becoming increasingly popular in international practice, and it is virtually impossible and economically impractical to stop its development. The emergence of cryptocurrency with a high degree of financial novelty leads to revolutionary changes in monetary relations, and puts us at a new stage in the evolution of money. It causes new challenges on the monetary and payment systems and prompts governments to adapt their financial institutions accordingly. The main directions of improvement of the regulation of the cryptocurrency turnover are outlined on the basis of comparison of the current legislation in Ukraine with the economically developed countries of the European Union and the world.

Keywords: cryptocurrency; landing; electronic money; virtual currency bitcoin; fiat money; cryptocurrency exchanges. 